\title{
Business Process Reengineering (BPR) Initiatives in Public Sector of Pakistan
}

\begin{abstract}
Muhammad Nauman Habib ${ }^{1}$, Dr. Waseef Jamal ${ }^{2}$
Abstract

This study examined three cases from the service sector to examine the BPR initiative in the public sector of Pakistan. The purpose of this study was to investigate and compare reengineering efforts in the public sector and to find an answer to the question, 'How are these initiatives taking place in developing countries. In-depth interviews were conducted with top management of all three organizations, and the planning documents were reviewed for understanding the planning, implementation, purpose, and performance of the BPR initiative. The background of the BPR process with a set of questions was extracted from literature on reengineering, and then the three cases (firms) were discussed with figures of the current and previous systems. Afterwards, information extracted from semi-structured interviews is presented using a qualitative data technique for comparative analysis and discussion. The study reveals that there are successes and failures in BPR projects of the same public sector (reasons of failure and success are discussed); however, it is a positive sign that government and concerned stakeholders are taking initiatives for public sector reform in Pakistan.
\end{abstract}

Keywords: Business Process Reengineering, Public Sector, Service Sector, Qualitative

\section{Introduction}

Organizations are facing numerous challenges worldwide e.g. technological changes, competition, consumer's demand, issues related to workforce, changes in climate and working conditions etc. has been changing rapidly. Thus, organizations are unable to stabilize because of the changes taking place in external as well as internal environment (Erim and Vayvay, 2010). Therefore, none of the current organizational strategies, organizational structure, business processes and organizational cultures are ideal and they need to be revised for the survival in this inconsistent changing environment (Reeves-Ellington, 1995).

To cope with these challenges and survive in this dynamic environment, organizations are relaying on tools for change (Habib, 2011). One of the most significant tool (method) used for change is Business Process Reengineering (BPR). BPR has emerged as the most powerful and appropriate tool to deal with the demands of any organization. It has been in practice since it was introduced by Hammer (1990) in US-Based firms and eventually BPR was recognized as the tool for success in both production

1 Ph.D. Management Sciences Student, Institute of Management Sciences, Peshawar.

2 Assistant Professor, Institute of Management Sciences, Peshawar. 
and services sectors of private as well as public sector. For example; Ranganathan and Dhaliwal (2001) collected evidences from Singapore base firms and found that 85\% firms were engaged in BPR. Similarly, in 1994, 69\% of USA based firms and 75\% of European firms were involved in reengineering (Champy, 1994). Most of the giant corporations has undergone through BPR in the recent past including; Ford, IBM, Kodak, Motorola, Sony etc. (Erim and Vayvay, 2010).

In developing countries like Pakistan, Bangladesh, Sri Lanka, India, and Asian Pacific countries, departments working under the Federal and Provincial government as well as state-owned enterprises are facing problems i.e. old and out dated systems, issues of scarce resources (budgets), issues in HR, financial management systems, and old paper work and filing system with weak infrastructure and lack of customer focus. Use of conventional administrative practices with tall hierarchy and centralized bureaucratic system are often reported for lengthy system and wastage of billions of amount with slow and delayed services to their citizens. Corruption is also reported at its peak in public sector organizations. Furthermore, public sector organizations are overemployed with political appointments in bureaucracy and lower position hence, limited resource, lack of technical expertise, lack of knowledge and interest of top management in reforms etc. are reasons for failure of reforms efforts (Zaheer et al., 2008, Siddiquee, 2007, Sarker, 2006).

Pakistan is a country with number of challenges i.e. social, political, and economic problems. Due to political manipulation and corruption this country's public sector, annually 2.4 million of public servants are unresponsive and corrupt. Lack of governance, lack of attention, interruption from military and inefficient bureaucracy has led public sector of Pakistan to the verge of destruction (Asian Report, 2010). In fiscal year 2012-13, US \$3.5billion were spent on reform of eight major state own enterprises resulted in loss due to ill system and infrastructure. Public sector organization's loses are affecting governmental targets as well as the whole economy. In 2012 these loses reached as much as $\$ 4.0$ billion per year (Siddiqui, 2013). Pakistan is ranked among top most corrupt countries list with the score of 2.5 (where $0=$ highly corrupt and $10=$ very clean). Pakistan is ranked 134 th most corrupt country among the list of 182 countries in corruption (Transparency International, 2011). Similarly, Gallup Pakistan (2012) conducted a survey from the citizens of Pakistan to find out what they dislike the most about Pakistan as a result 16\% responded as corruption being the most disliked element in Pakistan. Pakistan's current deficit has reached level of $7.5 \%$ which is mainly considered due to unfair taxation measures (Kiani, 2013).

At the time when fore stated problems were faced by developed countries during 1980s-90s, they decided to bring radical changes in the business processes of public sector organizations. Management tool called Business Process Reengineering (BPR) 
was adopting from Private Sector. With the help of this tool processes that were long and lengthy, having so many unnecessary steps that resulted in wastage of time and resources, outdated manual systems, and those steps of processes that provided chances for corruption were all reengineered and a complete new slate processes were implemented(Hammer and Champy, 1993, Davenport, 1993).

Numerous studies conducted and published on the assessment of BPR initiatives from time to time e.g. Ranganathan and Dhaliwal (2001) reported BPR efforts in Singapore, Hammer and Champy (2001) reported evidences from US and Europe, Grint and Willcocks (1995) in Australia, MacIntosh (2003a) conducted a study on BPR in UK, Martinsons (2004), He (2004b) in China, Belmiro et al. (2000b) reported BPR in Brazil and UK, and Habib and Wazir (2012), Zaheer (2009) reported BPR initiatives in Pakistan. Most of these studies are reported from private sector and were focusing on identification of the processes (that were reengineered) and the results. Literature has very limited to offer from public sector's reengineering efforts and they are mostly reported from developed world. There is a lack of studies from public sector's BPR efforts in under developing world. This study will focus on filling the gap by providing a comprehensive and in-depth analysis to the approach in public sector towards BPR in under developing economies. This study will also help in comparing BPR practices of this part of world with developed world.

\section{Research Question}

1. What are the reasons and results of BPR in a developing country?

2. How BPR is approach in public sector of a developing country?

3. What changes were made to the organization due to adjust BPR initiatives?

4. What is the relationship of ERP and BPR?

5. What are the lessons learned from BPR initiatives in public sector of developing country?

\section{Background}

Hammer and Champy (1993) defined BPR as "the fundamental rethinking and radical redesign of business process to achieve dramatic improvement in critical contemporary measures of performance, such as cost, quality, service and speed". BPR has emerged as the most important managerial practice for the improvement of firm's performance in this century (Sychowicz, 2008).

In this definition, four core components of reengineering has been identified 
i.e. fundamental, radical, dramatic and processes (Sychowicz, 2008). "Fundamental" means an initiatives to change the obsolete way of conducting business and start from scratch i.e. how they operate and the way they do the business (Hammer and Champy, 2001). Second component (radical redesign) means getting into the roots of the business process and changing accordingly (Stahl, 1998, Hammer and Champy, 2001). Third component of BPR is known as dramatic which aims at improving firm's performance dramatically i.e. not a small change but a drastic change in the output of an organization. Thus, to improve firms' performance, they need to demolish old process and start a new process (Hammer and Champy, 2001). Lastly, the forth component of BPR is identified as process where BPR aims on developing such a process through which a firm can attain its goals i.e. achieve radical improvements in cost, time, responsiveness, performance, quality, etc. (Browne and O'Sullivan, 1995).

Studies shows that the objectives of BPR are very clear and it covers all the aspects of business needs e.g. increasing revenues (Eisner, 2000), dramatic changes in profits and market share (Knights and Willmott, 2000), improving quality of customer service (Ranganathan and Dhaliwal, 2001), induction of new products and services (Choi, 1995), reducing operating cost (Knights and Willmott, 2000, Maglitta, 1995), streamlining operations (Colin and Coulson, 1997), meeting client's demands (Albizu and Olazaran, 2006), and to overcome crises situation (Hammer and Stanton, 1995).

In the era of globalization, organizations are considering and utilizing I.T. as an integral part of operations. Information technology plays vital role in BPR projects and acts as a primary enabler in reengineering process (Davenport, 1993, Hammer and Champy, 1993, Al-Mashari et al., 2001). In this century, computer and IT has replaced the old method of paper work in organizations all over the globe. According to Venkartraman (1991b), the birth of BPR was mainly to align IT with strategy and to enhance efficiency of operations. Moreover, Enterprise resource planning (ERP) has emerged as a helping hand to management and as well as to employees and it has helped organizations in achieving efficiency and effectiveness (Ranganathan and Dhaliwal, 2001). Thus, ERP supports the objectives of BPR and the factors that force organizations to reengineer are similar to the factors of ERP (Smith, 2002). However, it is not necessary that BPR project always involve ERP implementation nor it is necessary to reengineer process to accommodate ERP in an organization (Huang and Palvia, 2001).

Jurisch et al. (2012) in their study (based on 67 previous studies on public as well as private sectors) discussed that the project scope, top management commitment, availability of resources, project management, and change management are equally important for the success of BPR in both public and private sectors. Whereas the differences between these sectors is mainly due to the readiness to bring change in 
private sector and public sector management's status quo nature, and the differences in the objectives and benefits among these sectors. The authors further elaborated that the public sector has two major advantages over private sector i.e. a small-scale approach to BPR will increase success rates of BPR endeavors in the public sector and, sharing of knowledge and experiences via trans-institutional knowledge management platforms would positively impact the implementation of BPR in public administrations. On the other hand MacIntosh (2003b) found BPR equally important and in practice in both sectors with no significant differences in public and private organizations. Furthermore, BPR is more common and in practice in private sector as compared to public sector (Ranganathan and Dhaliwal, 2001).

In Pakistan, departments working under federal and provincial government (stateowned enterprises) are facing with problems like old and out dated systems i.e. issues of scarce resources (budgets), issues in hiring, financial management systems, and old paper work and filing system with weak infrastructure and lack of customer focus. Use of conventional management practices, tall and centralized bureaucratic system are often reported for wastage of billions of rupees and delay in delivering services to the residents (Zaheer et al., 2008). Thus, for sustainable development and effective utilization of resources, government of Pakistan has undertaken several reengineering initiatives at federal as well as provincial level. These efforts aimed to reengineer customer services with the help of introducing one window concept powered by automation i.e. computerized database and E-Governance (Habib and Wazir, 2012).

\section{Methodology}

The paradigm of research was anti-positivist and the philosophy of the study was based on realism (as recommended by Guba and Lincoln (1994) for such kind of studies) therefore, following inductive approach for this (qualitative) study because of the nature of research (See for example Mackenzie and Knipe (2006)) i.e. to first collect the evidences (data) from public sector regarding BPR initiatives undertaken by the provincial government of KPK.

\subsection{Sample Selection}

According to provincial government website, there were seven reengineering cases in provincial government. Three public sector organizations had completed the BPR processes whereas the remaining cases were in the initial stage of planning and transition. Thus, as a requirement (to answer the research questions) only those cases were selected as a sample for this study that has already undergone through BPR. The identity of departments (organizations) is not disclosed due to the ethical requirement thus, they are referred as CDLA, Edu1 and Hosp1. All three cases were selected from 
public (provincial) sector to fill the gap i.e. to understand the BPR initiative in the public sector of developing world.

\subsection{Data collection}

Semi-structured interviews were conducted with each of the organizational heads. Interviews were conducted for the reason to get in-depth details about the BPR projects and to study the process closely (Bernard, 2012). An official letter was drafted and sent to the head of organizations showing the intent of study and to make and to make an appointment with the concern personnel. Three days after dispatching of letter a call was made to confirm the receiving of letter and to make an appointment with the head of organization to discuss the study aim and objectives. Initial meeting was held that lasted for 20-30 minutes in the office of head of organization (i.e. director). During initial meeting, CDLA authorized Manager Operations and IT as a suitable person to be interviewed. Edu1 authorized and directed Secretary Establishment section and Hosp1 nominated Manager Operations and IT. All of them were holding similar level positions in their respective organizations and were from top management. In addition they remained a part of organization before reengineering, during planning and after the processes were reengineered. Another letter was drafted and directed towards these personnel to have an official appointment for an interview. Interviews were scheduled and confirmed on telephone in their concern offices. Both authors went to conduct interviews (one asking questions and the other taking notes). Interview sessions were also recorded using voice recorder so that it can be analyzed and used for data extraction in later stages. Interview session lasted on average about 70 minutes with each interviewee. Initial questions of semi-structured interview were extracted from the previous studies of MacIntosh (2003b), Belmiro et al. (2000c), Sentanin et al. (2008), Goksoy et al. (2012), Coulson-Thomas (1995). Process followed for data analysis was based on the instructions byCreswell (2002), Miles and Huberman (1994).

\subsection{Data Analysis}

Information collected through interviews was first manually recorded and then tabulated in MS Word to make it more meaningful, then in second stage (formalization) the general sense was given to the talk. During 3rd stage, the data was coded as per guidelines of Miles and Huberman (1994) i.e. data was divided into categories (theme) using theory-driven codes and then the responses were subcategorized so that it gets simplified and structured by using axial coding technique. This process of coding was done by using a qualitative data analysis software ATLAS.ti7. During the last stage (generating meaning) data was organized in such a manner that it easily reflects the meaning and clearly show the whole of BPR initiative activities (based on 
the research questions) individually of one organization as well as helps in comparing the processes of all three. Furthermore, this qualitative analysis helps reader in better understanding of complete in-depth of the BPR initiatives in this part of the world and can easily draw the similarities as well as differences among the various applications of BPR processes(Babbie, 2012). On the basis of themes and subthemes, information has been presented into a tabulated form in the results and discussion part of this study.

\section{The Cases (Before and After)}

Case 1: CDLA is a provincial public sector's department that issues driving licenses to the citizens. Before 2007, the authority of issuing licenses was with the district traffic police where all the process was manual. Operational and customer services were provided without any standard processes and cycle i.e. visit the district traffic police office with a photocopy of National Identity Card (NIC), photographs, then fill the form and sign it from officer of BPS 17 or above. After that go to district hospital for medical examination and certificate, then appear in driving test and interview, and deposit License fee in selected bank branches and return with the slip again to the issuance authority. After that, a handwritten card was issued with picture of the card holder and entry was made in a register (record book). However, if a person is having reference or any relative in the police then a card was issued directly without any procedure. This system had number of problems including; low contribution margin, no control charts, no proper flow time i.e. if you had reference then within one day the license was issued otherwise it may take a month. Another major problem was that of bogus licenses were issued and reported that almost $50 \%$ of driving licenses issued were having no record in the office throughout the province which indicated corruption and frauds in the system. Similarly, the issue of authentication and acceptance of driving licenses was becoming one of the great concern and the citizens of this province were facing problems when they travel to the capital or to the other provinces. Third major concern was of the revenue generation i.e. only $20 \%$ of the revenue was generated as compared to the annual target thus; it was creating problems for the provincial government in reaching its targets and resulting in deficit every year. Forth major issue was of the record i.e. there was no coordination and proper record maintenance and also there was no mechanism to keep a proper (centralized) record of licenses issued and revenue. Lastly, the customers (citizens) were not satisfied with the process and system due to which distrust on system, fatigue, and wastage of time were found very common among them (See Figure I).

To overcome these problems and issues, traffic police in collaboration with (sponsor) Directorate of Science and IT (DOST) decided to reengineer the current system and to modernize the existing process. During the course of time client has 
identified a few processes that were lengthy and time consuming and few new processes need to be implemented to meet the day to day requirement of the client and to increase the efficiency of the system. International standard cards with RFID chip was designed, all district offices were automated, all offices were connected to the server and printing machine located in head office (see network diagram in Figure 1a). Moreover there were also some limitations in the previous version of application in Reporting, Human Resource and Printing module which they want to overcome. Furthermore, the accountability, reduce fraud and corruption, introduction of audit and trail system, and easy access to record were also considered as a part of reengineering. This reengineering has been successfully implemented and has set a great example that BPR is working effectively in the struggling economies. Detailed review of the BPR in CDLA is discussed in the next section of this paper.

Case 2: Edu1 is an educational assessment authority (board) that is responsible for dealing with all aspects of secondary and higher secondary education in the province. Registration of schools and colleges, registration of students for secondary and higher secondary education, issuance of roll numbers, conducting exams (annual and supplementary), checking exam papers and declaring results, issuance of certificates and mark sheets, and verification services etc. are the major responsibilities of Edu1. One of the major concern of Edu1 was delay in services to the students e.g. registration process, issuance of marks sheet and certificate, migration, rechecking and retotaling, delays in issuance of roll number slips for inter or secondary school exams, and also in display of results (variability). Another problem was the number of cases that Edu1 was dealing were increasing due to that hundreds of service seekers were moving around from one office to another for signature, for form submission, for corrections, for information etc. every day (directional issues). The nature of work and sensitivity of records required Edu1 to minimize the interaction of students with the staff and to reduce the customer contact for this purpose changes were made in order to facilitate students and to provide specialized services with minimum contact for the smooth running of operations (See Figure-II).

In 2004, an initiative was taken to separate customer services from the remaining functional areas of an organization with the introduction of one window services. 10 specialized windows were created along with the bank branch to facilitate the students in submitting service charges. One window started its operations manually in January 2004 whereas in a mean time software was developed and installed in December 2004 for atomizing the one window operations. To facilitate the citizens of the province further, all types of forms were made available online on the website. Another initiative to facilitate customers was of declaration of result online, to make available the roll number slips online, to upload date sheet online, and to provide 
search option related to examination hall and result. Detail of reengineering initiative and its effectiveness is discussed in later part of this study.

Case 3: Hosp1 is one of the largest public sector's hospitals of the province, providing healthcare services to thousands of citizens every year. Every department of Hosp1 was working independently therefore, lack of coordination and communication was one of the major problems for top management. Another major problem was faced by the recipients of healthcare services and their attendant's i.e. from reception to medical examination and from registration to consultation there was no identity and record. No history on record, fatigue for attendants as they were asked many times to go to laboratory, for X-Ray report collection, to meet doctor, to submit dues, waiting in long queues, and to arrange blood etc. were common problems for delays. To overcome these problems an external consultant was hired in 2012 to study the processes and come up with a solution. Thus, upon analysis, the consultant recommended that this problem can be overcome if the organization takes advantage of IT. When the healthcare service seeker enters, he/she should be given a software generated ID number. Every department should be connected through local networking and the record should go to the database. Everyone who is dealing with the patient should enter his/her information into the system and it should help to keep a history as well as a report can be generated on daily basis about the activities (See Figure-III).

\section{Result and Discussion}

Initial inquest illustrated that all cases of BPR in public sector organization were initiated at different time period e.g. Edu1 in 2004, CDLA in 2007 while Hosp1 reengineered their process in 2012. During these BPR projects, CDLA and Edu1 reengineered their customer services whereas Hosp1 reengineered their communication channel and records (database). While asking about the reason for reengineering it was revealed that BPR was initiated to overcome problems in the old process (see Table I: 103). In CDLA, manual system was time consuming; issues of corruption by employees, accountability, and customer satisfaction were main problems. Furthermore, the card issued at the end was of no standard, handwritten and issued by every district independently and was having no proper record with the authority (see case1 for details). On the other hand, Edu1 was concerned about the secrecy of their activities, efficiency, and fatigue that their customers were facing (as discussed in detail in Case2). In Hosp1 the management of hospital faced problems in maintaining record of all health service seekers as well as interdepartmental activities (as discussed in case3).

CDLA involved cross-functional teams and bureaucracy to overcome these problems whereas Edu1 only involved there top management in finding solution to 
the problems faced. On the other hand, Hosp1 involved top management, IT and Administration in decision making. Furthermore, Hosp1 also involved external BPR consultant in finding solution to the problem.

BPR project mainly consist of two phases (i.e. planning and implementation) and BPR cycle suggests four steps should be taken in BPR project (i.e. 1) Identify process, 2) Review, updates, analyze as-is, 3) design to-be, and 4) test and implement. First three steps are related to planning and step 4 is of implementation. Cases in this study show that a significant time was devoted to both phases of BPR project (see Table I: 106) however, hosp 1 did not go through pilot test before implementing changes in the overall process. Furthermore, it was also found that BPR initiative in public sector was mostly reactively approached however, to a minor extent focus was proactive as well. This is an indication of the fact that top management lacks vision and is more concerned about finding solution to the problems faced rather than getting equipped for future in advance. Nature of BPR initiatives in CDLA was radical i.e. automation of whole process as a replacement of manual paperwork, initiation of one window operations, centralized database and license printing, introduction of audit and trial system in CDLA. Similarly Edu1 also went through radical change i.e. one window operations students having any kind of work with concerned departments. While Hosp1 was undergone through incremental change in the process i.e. connected all departments through network and database and improved the communication channels between management and departments (see Table I: 108, 109).

Table I: Basic Information about BPR Project

\begin{tabular}{|c|c|c|c|c|}
\hline ID & $\mathrm{Q} \#$ & CDLA & Edu1 & Hosp1 \\
\hline 101 & $\begin{array}{l}\text { Starting } \\
\text { date of BPR } \\
\text { Project }\end{array}$ & 2007 & 2004 & 2012 \\
\hline 102 & $\begin{array}{l}\text { Processes Re- } \\
\text { engineered }\end{array}$ & $\begin{array}{l}\text { Card Issuance process } \\
\text { (Customer services) }\end{array}$ & Student's services & $\begin{array}{l}\text { Communication and } \\
\text { records }\end{array}$ \\
\hline 103 & $\begin{array}{l}\text { Reasons for } \\
\text { Reengineer- } \\
\text { ing }\end{array}$ & $\begin{array}{l}\text { Standardization of } \\
\text { driving license, Re- } \\
\text { duce fraud and corrup- } \\
\text { tion, Introduction of } \\
\text { audit and trail system, } \\
\text { Easy access to record, } \\
\text { Accountability, One } \\
\text { window operations, } \\
\text { Time and cost mini- } \\
\text { mization, Customer } \\
\text { satisfaction. }\end{array}$ & $\begin{array}{l}\text { To bring efficiency } \\
\text { in services pro- } \\
\text { vided, To provide } \\
\text { specialized services } \\
\text { at one place, To } \\
\text { reduce the fatigue } \\
\text { and time wastage of } \\
\text { students }\end{array}$ & $\begin{array}{l}\text { The recipients of healthcare } \\
\text { services and the attendants } \\
\text { were facing. No proper } \\
\text { record and previous history } \\
\text { was creating problems. } \\
\text { Furthermore, the office of } \\
\text { MS was not having any re- } \\
\text { cord of activities of various } \\
\text { departments therefore; the } \\
\text { process was reengineered to } \\
\text { overcome these problems. }\end{array}$ \\
\hline
\end{tabular}




\begin{tabular}{|c|c|c|c|c|}
\hline 104 & $\begin{array}{l}\text { Employees/ } \\
\text { organizations } \\
\text { involved in } \\
\text { planning and } \\
\text { implementa- } \\
\text { tion }\end{array}$ & $\begin{array}{l}\text { Cross-functional teams } \\
\text { and bureaucracy }\end{array}$ & $\begin{array}{l}\text { Top management } \\
\text { only }\end{array}$ & $\begin{array}{l}\text { Management, IT and Ad- } \\
\text { min departments }\end{array}$ \\
\hline 105 & $\begin{array}{l}\text { External } \\
\text { consultant } \\
\text { involved? }\end{array}$ & $\mathrm{NO}$ & $\mathrm{NO}$ & YES \\
\hline 106 & $\begin{array}{l}\text { Time con- } \\
\text { sumed (Phase } \\
\text { wise)? }\end{array}$ & $\begin{array}{l}\text { Planning: } 01 \text { year } \\
\text { Pilot testing in one } \\
\text { district: } 6 \text { months } \\
\text { Overall implementa- } \\
\text { tion: } 2 \text { years }\end{array}$ & $\begin{array}{l}\text { Planning: } 6 \\
\text { months, Manual } \\
\text { operations: } 11 \\
\text { months, automated } \\
\text { services implemen- } \\
\text { tation: } 6 \text { months }\end{array}$ & $\begin{array}{l}\text { Planning: } 9 \text { months, Imple- } \\
\text { mentation: } 1 \text { year }\end{array}$ \\
\hline 107 & $\begin{array}{l}\mathrm{BPR} \text { as a } \\
\text { proactive } \\
\text { or reactive } \\
\text { approach? }\end{array}$ & $\begin{array}{l}\text { To some extent reengi- } \\
\text { neering was proactive } \\
\text { and to some extent it } \\
\text { was reactive i.e. solu- } \\
\text { tion to the problems. }\end{array}$ & $\begin{array}{l}70 \% \text { reactive and } \\
30 \% \text { proactive due } \\
\text { to increase in use } \\
\text { of IT }\end{array}$ & Reactive approach \\
\hline 108 & $\begin{array}{l}\text { Nature of } \\
\text { Change? }\end{array}$ & $\begin{array}{l}\text { Complete slate/ } \\
\text { radical: Completely } \\
\text { changing old system } \\
\text { with new process }\end{array}$ & $\begin{array}{l}\text { Radical: Removal of } \\
\text { unnecessary steps } \\
\text { and launching one } \\
\text { window operations }\end{array}$ & $\begin{array}{l}\text { Incremental: Adjustment } \\
\text { in communication channel } \\
\text { and ICT network }\end{array}$ \\
\hline 109 & $\begin{array}{l}\text { Significant } \\
\text { changes in } \\
\text { old process? }\end{array}$ & $\begin{array}{l}\text { One Window } \\
\text { Operation, voucher } \\
\text { verification, ERP }\end{array}$ & $\begin{array}{l}\text { One window oper- } \\
\text { ations, specialized } \\
\text { (distributed) duties } \\
\text { and tasks }\end{array}$ & $\begin{array}{l}\text { Computer generated } \\
\text { reference numbers, database } \\
\text { for record of activities, ICT } \\
\text { interface }\end{array}$ \\
\hline
\end{tabular}

Upon further investigation for in depth analysis of BPR initiative in this part of world, it was found that there were changes (adjustments) made in the overall organization to make sure the success of project. Changes in an overall organization due to reengineering are shown in Table II. These changes includes rightsizing of HR and training programs, changes in organizational focus, beliefs and values, reporting hierarchy, and organizational structure. The effect of such adjustment proved to be fruitful and it has contributed in the success of BPR initiative. CDLA had made most of the adjustments to manage organizational changes as necessary whereas in contrast hosp1 made very minor adjustments to accommodate change. 


\section{Table II: Changes in organization due to BPR}

\begin{tabular}{|c|c|c|c|c|}
\hline ID & $\mathrm{Q} \#$ & CDLA & Edu1 & Hosp1 \\
\hline 201 & $\begin{array}{l}\text { Changes } \\
\text { in Human } \\
\text { Resource }\end{array}$ & $\begin{array}{l}50 \% \text { new staff hired } \\
\text { due to change in } \\
\text { process i.e. computer } \\
\text { operators }\end{array}$ & $\begin{array}{l}\text { No change: Inter-de- } \\
\text { partmental transfers }\end{array}$ & $\begin{array}{l}\text { Hired Computer and } \\
\text { Networking staff with CS } \\
\text { background education }\end{array}$ \\
\hline 202 & $\begin{array}{l}\text { To whom } \\
\text { training was } \\
\text { provided? }\end{array}$ & $\begin{array}{l}100 \% \text { staff i.e. old and } \\
\text { new employees }\end{array}$ & $\begin{array}{l}\text { Only concerned i.e. } \\
\text { customer services } \\
\text { officers }\end{array}$ & $\begin{array}{l}\text { Front office staff and IT } \\
\text { department staff }\end{array}$ \\
\hline 203 & $\begin{array}{l}\text { Type of } \\
\text { training }\end{array}$ & $\begin{array}{l}\text { I.T and basic com- } \\
\text { puter }\end{array}$ & $\begin{array}{l}\text { New process, cus- } \\
\text { tomer dealing, I.T } \\
\text { training }\end{array}$ & $\begin{array}{l}\text { I.T Training and database/ } \\
\text { software usage training }\end{array}$ \\
\hline 204 & $\begin{array}{l}\text { Change in } \\
\text { organization- } \\
\text { al focus? }\end{array}$ & Significant & Significant & Very little \\
\hline 205 & $\begin{array}{l}\text { Change in } \\
\text { Org. Values } \\
\text { and Beliefs? }\end{array}$ & $\begin{array}{l}\text { To minor extent i.e. } \\
\text { To provide quality } \\
\text { and timely services to } \\
\text { customers. }\end{array}$ & Very little changes & None \\
\hline 206 & $\begin{array}{l}\text { Changes in } \\
\text { reporting } \\
\text { hierarchy? }\end{array}$ & $\begin{array}{l}\text { To some extent i.e. } \\
\text { Due to change in pro- } \\
\text { cess and introduction } \\
\text { of ERP }\end{array}$ & No changes & No changes \\
\hline 207 & $\begin{array}{l}\text { Change in } \\
\text { Organization- } \\
\text { al structure? }\end{array}$ & $\begin{array}{l}\text { Minor, Addition of } \\
\text { database management } \\
\text { and one window staff }\end{array}$ & $\begin{array}{l}\text { Yes a slight change } \\
\text { in structure to } \\
\text { accommodate the } \\
\text { new department } \\
\text { of one window } \\
\text { services }\end{array}$ & No changes \\
\hline 208 & $\begin{array}{l}\text { Usage of } \\
\text { cross-func- } \\
\text { tional teams }\end{array}$ & $\begin{array}{l}50 \% \text { changes were } \\
\text { made to develop } \\
\text { cross-functional teams } \\
\text { and improve the flow } \\
\text { of work. }\end{array}$ & $\begin{array}{l}70 \% \text { changes were } \\
\text { made and from } \\
\text { accounts to the } \\
\text { front office, from } \\
\text { admission to the } \\
\text { results }\end{array}$ & $\begin{array}{l}20 \% \text { increase in developing } \\
\text { and using cross-functional } \\
\text { teams, mainly for planning } \\
\text { and M\&E }\end{array}$ \\
\hline 209 & $\begin{array}{l}\text { Use of new } \\
\text { procedures, } \\
\text { rules and } \\
\text { regulations }\end{array}$ & $\begin{array}{l}100 \% \text { changes were } \\
\text { made to make sure the } \\
\text { successful implemen- } \\
\text { tation of BPR and to } \\
\text { support the changes in } \\
\text { processes. }\end{array}$ & $\begin{array}{l}40 \% \text { changes were } \\
\text { made in the current } \\
\text { procedures howev- } \\
\text { er; no changes took } \\
\text { place in rules and } \\
\text { regulations. }\end{array}$ & $\begin{array}{l}\text { Very minor (10-15\%) chang- } \\
\text { es in procedure of counters } \\
\text { and data entry into databas- } \\
\text { es. No changes in rules and } \\
\text { regulations. }\end{array}$ \\
\hline
\end{tabular}




\begin{tabular}{|c|c|c|c|c|}
\hline 210 & Use of IT & $\begin{array}{l}\text { The whole organiza- } \\
\text { tional system has been } \\
\text { changed to technology } \\
\text { driven system. }\end{array}$ & $\begin{array}{l}60-70 \% \text { of the } \\
\text { whole organization- } \\
\text { al processes are now } \\
\text { using IT }\end{array}$ & $30 \%$ and increasing \\
\hline 211 & $\begin{array}{l}\text { Customer ori- } \\
\text { enteers and } \\
\text { feedback }\end{array}$ & $\begin{array}{l}\text { The new process is cus- } \\
\text { tomer driven and their } \\
\text { feedback has helped } \\
\text { us reach this level and } \\
\text { sustain the quality of } \\
\text { services }\end{array}$ & $\begin{array}{l}100 \% \text { based on } \\
\text { customer need for } \\
\text { better service }\end{array}$ & $\begin{array}{l}30 \% \text { because the changes in } \\
\text { processes are mostly organi- } \\
\text { zational need based }\end{array}$ \\
\hline 212 & $\begin{array}{l}\text { Changes in } \\
\text { front office }\end{array}$ & $\begin{array}{l}\text { Significant changes } \\
\text { were made in the front } \\
\text { office to facilitate } \\
\text { customers under one } \\
\text { window services. }\end{array}$ & Significant changes & Minor changes \\
\hline 213 & $\begin{array}{l}\text { Changes to } \\
\text { back office } \\
\text { (Processing) }\end{array}$ & $\begin{array}{l}\text { A centralized database } \\
\text { server and cards } \\
\text { printing machines } \\
\text { are brought into the } \\
\text { same premises. Cards } \\
\text { printing have been } \\
\text { kept centralized to } \\
\text { reduce corruption and } \\
\text { misuse. }\end{array}$ & $\begin{array}{l}\text { To the great extent } \\
\text { due to automation }\end{array}$ & To the minor extent \\
\hline 214 & $\begin{array}{l}\text { Admin and } \\
\text { HR office }\end{array}$ & $\begin{array}{l}\text { Very minor changes } \\
\text { i.e. computerization } \\
\text { of records and record } \\
\text { keeping. }\end{array}$ & $\begin{array}{l}\text { Minor changes took } \\
\text { place }\end{array}$ & Not at all \\
\hline
\end{tabular}

It was also found that Enterprise Resource planning (ERP) and IT played a vital and a central role in the success of BPR. All three cases showed the importance of technology as a key enabler and reason for brining desirable results. Details of ERP and IT role are shown in Table III. With the help of automation communication within organization improved significantly. Customized software helped organizations in improving the performance, and was helpful in lowering cost as well as process completion time. Furthermore, the accountability has also improved in CDLA as well as it helped generating desired information on timely basis. 
Table III: Role of ERP

\begin{tabular}{|c|c|c|c|c|}
\hline ID & Q\# & CDLA & Edu1 & Hosp1 \\
\hline 301 & $\begin{array}{l}\text { Satisfaction } \\
\text { from ERP? }\end{array}$ & $\begin{array}{l}\text { Highly satisfied be- } \\
\text { cause of the custom- } \\
\text { ized and program as } \\
\text { required. }\end{array}$ & $\begin{array}{l}\text { Producing results as } \\
\text { expected }\end{array}$ & Not sure \\
\hline 302 & $\begin{array}{l}\text { Role of ERP } \\
\text { in lowering } \\
\text { cost }\end{array}$ & $\begin{array}{l}\text { To some extent. Cost } \\
\text { increase a bit due to } \\
\text { RFID card price. }\end{array}$ & $\begin{array}{l}\text { Yes it helped in } \\
\text { lowering the cost of } \\
\text { printing. }\end{array}$ & No difference \\
\hline 303 & $\begin{array}{l}\text { Improvement } \\
\text { in cross-func- } \\
\text { tional team's } \\
\text { and depart- } \\
\text { ment's collab- } \\
\text { oration }\end{array}$ & $\begin{array}{l}\text { Yes, it has played vital } \\
\text { role in improving col- } \\
\text { laboration with ease } \\
\text { and saved time }\end{array}$ & $\begin{array}{l}\text { Yes collaboration } \\
\text { has improved from } \\
\text { the previous process }\end{array}$ & $\begin{array}{l}\text { Yes it has improved and } \\
\text { narrowed the communica- } \\
\text { tion gap }\end{array}$ \\
\hline 304 & $\begin{array}{l}\text { Flexibility } \\
\text { due to ERP }\end{array}$ & $\begin{array}{l}\text { Yes for authorized } \\
\text { personals only. ERP is } \\
\text { not allowing everyone } \\
\text { to modify the data } \\
\text { once entered due to } \\
\text { the flaw of previous } \\
\text { manual system i.e. } \\
\text { reports of frauds and } \\
\text { corruption }\end{array}$ & $\begin{array}{l}\text { No flexibility was } \\
\text { not among the } \\
\text { objectives }\end{array}$ & $\begin{array}{l}\text { Yes it has greater flexibility } \\
\text { where needed }\end{array}$ \\
\hline 305 & $\begin{array}{l}\text { Increase } \\
\text { in process } \\
\text { efficiency due } \\
\text { to ERP? }\end{array}$ & $\begin{array}{l}\text { Yes beyond expecta- } \\
\text { tions }\end{array}$ & $\begin{array}{l}\text { Yes to the most } \\
\text { extent }\end{array}$ & $\begin{array}{l}\text { It has helped in improving } \\
\text { efficiency }\end{array}$ \\
\hline 306 & $\begin{array}{l}\text { Has ERP re- } \\
\text { duced elapsed } \\
\text { time-cycle? }\end{array}$ & To the great extent & $\begin{array}{l}\text { Process elapsed } \\
\text { time depends on } \\
\text { the number of cases } \\
\text { per day. }\end{array}$ & No \\
\hline 307 & $\begin{array}{l}\text { Improvement } \\
\text { in communi- } \\
\text { cation due to } \\
\text { ERP? }\end{array}$ & $\begin{array}{l}\text { ERP has improved } \\
\text { communication how- } \\
\text { ever, not to full extent }\end{array}$ & $\begin{array}{l}\text { Communication } \\
\text { lines has improved } \\
\text { with the adaptation } \\
\text { ICT }\end{array}$ & $\begin{array}{l}\text { Still working on improving } \\
\text { the communication as it is } \\
\text { huge organization and it } \\
\text { will take time getting use to } \\
\text { with it. }\end{array}$ \\
\hline
\end{tabular}




\begin{tabular}{|c|c|c|c|c|}
\hline 308 & $\begin{array}{l}\text { ERP provides } \\
\text { timely and } \\
\text { accurate } \\
\text { information? }\end{array}$ & $\begin{array}{l}\text { Yes, with a single click } \\
\text { all desired informa- } \\
\text { tion and reports are } \\
\text { generated. }\end{array}$ & $\begin{array}{l}\text { Yes with a single } \\
\text { click it has number } \\
\text { of information gen- } \\
\text { erating capability } \\
\text { with accuracy }\end{array}$ & $\begin{array}{l}\text { Yes for decision making a } \\
\text { variety of information and } \\
\text { reports can be generated }\end{array}$ \\
\hline 309 & $\begin{array}{l}\text { With the } \\
\text { help of ERP, } \\
\text { communica- } \\
\text { tion with top } \\
\text { management } \\
\text { has improved } \\
\text { and timely } \\
\text { support has } \\
\text { provided }\end{array}$ & $\begin{array}{l}\text { User interface pro- } \\
\text { vides options to every } \\
\text { user to communicate } \\
\text { with anyone in an } \\
\text { organization and it } \\
\text { has also improved } \\
\text { the support from the } \\
\text { top management on } \\
\text { regular as well as need } \\
\text { basis. }\end{array}$ & Not applicable & $\begin{array}{l}\text { Yes the system provides } \\
\text { option of communicating } \\
\text { with anyone inside and } \\
\text { it also facilitate in case of } \\
\text { any complaint as well as a } \\
\text { committee has been estab- } \\
\text { lished to look after the staff } \\
\text { grievance cases. }\end{array}$ \\
\hline
\end{tabular}

ERP was found to be the main reason for reengineering in CDLA whereas, in Edu1 ERP was introduced after reengineering the customer services. Innovative technology and use of IT is an integral part of BPR thus, the public sector organizations in this part of world have realized its importance and are utilizing it properly. In Hosp1 networking took place as well as a database was installed however, it was not covering the overall organizational requirements. Whereas in Edu1 ERP and e-services were initiated but not at the time of reengineering. It has been shown that directly or indirectly EPR and IT remained a part of all reengineering processes in these cases. To expand the theme further, questions were asked to clarify the relation of ERP and BPR and it has been found that ERP was a part of BPR in CDLA and Hosp1 whereas in Edu1 it was implemented after 11 months of processes reengineered (See Table IV).

Table IV: ERP and BPR

\begin{tabular}{|l|l|l|l|l|}
\hline ID & Q\# & CDLA & Edu1 & Hosp1 \\
\hline 411 & $\begin{array}{l}\text { Was Reengi- } \\
\text { neering a } \\
\text { part of ERP } \\
\text { implementa- } \\
\text { tion? }\end{array}$ & $\begin{array}{l}\text { Yes, to implement } \\
\text { ERP as a replacement } \\
\text { of manual system, an } \\
\text { organization needed } \\
\text { to undergo through a } \\
\text { reengineering process }\end{array}$ & $\begin{array}{l}\text { No ERP was imple- } \\
\text { mented after one } \\
\text { year of reengineer- } \\
\text { ing }\end{array}$ & $\begin{array}{l}\text { Yes basically the aim was to } \\
\text { upgrade the system and to } \\
\text { fix the problems for smooth } \\
\text { transformation, reengineer- } \\
\text { ing was needed. }\end{array}$ \\
\hline
\end{tabular}




\begin{tabular}{|l|l|l|l|l|}
\hline 412 & $\begin{array}{l}\text { Did BPR take } \\
\text { place to take } \\
\text { advantage of } \\
\text { ERP and I.T? }\end{array}$ & $\begin{array}{l}\text { Yes, to cope with the } \\
\text { dynamic technolog- } \\
\text { ical changes taking } \\
\text { place across the globe } \\
\text { and changes in the } \\
\text { demands of customers } \\
\text { and also to improve } \\
\text { organization. }\end{array}$ & No & $\begin{array}{l}\text { Yes, as a part of a project to } \\
\text { make all hospitals linked via } \\
\text { database and network for } \\
\text { better and fast correspon- } \\
\text { dence }\end{array}$ \\
\hline 413 & $\begin{array}{l}\text { ERP software } \\
\text { was custom- } \\
\text { ized and } \\
\text { reengineering } \\
\text { took place as } \\
\text { required? }\end{array}$ & Yes & Yes & Yes \\
\hline
\end{tabular}

During interview the most interesting and important part was asking about the results and achievements of BPR project. The most successful reengineering was proved to be CDLA as the quality of services, number of customers, revenue and time-cycle were improved dramatically. Followed by Edu1 and Hosp1 was unable to achieve objectives of improved quality, customer satisfaction (see Table $\mathrm{V}$ for details).

Table V: BPR achievements

\begin{tabular}{|l|l|l|l|l|}
\hline ID & Q\# & CDLA & Edu1 & Hosp1 \\
\hline 501 & $\begin{array}{l}\text { Improved } \\
\text { productivity/ } \\
\text { services }\end{array}$ & $\begin{array}{l}\text { A great deal of im- } \\
\text { provement in services } \\
\text { and within the fiscal } \\
\text { year 2011-12 280,600 } \\
\text { customers were pro- } \\
\text { vided services which is } \\
\text { 22 times greater than } \\
\text { of the manual system. } \\
\text { At the beginning in } \\
\text { 2007,on an average } \\
\text { 350 cards were issued } \\
\text { on daily basis. }\end{array}$ & $\begin{array}{l}\text { Yes reengineering } \\
\text { has helped us in } \\
\text { improving services, } \\
\text { annully on average } \\
\text { 20,000 applications } \\
\text { are processed. }\end{array}$ & No effect \\
\hline 502 & $\begin{array}{l}\text { Improvement } \\
\text { in employees } \\
\text { satisfaction }\end{array}$ & $\begin{array}{l}\text { Employees are highly } \\
\text { satisfied and enjoy } \\
\text { working in cross-func- } \\
\text { tional teams and they } \\
\text { also enjoy interaction } \\
\text { with customers. }\end{array}$ & Not applicable & To little extent \\
\hline
\end{tabular}




\begin{tabular}{|c|c|c|c|c|}
\hline 503 & $\begin{array}{l}\text { Improvement } \\
\text { in revenues }\end{array}$ & $\begin{array}{l}\text { Revenue generated } \\
\text { on annually basis of } \\
\text { previous system is } \\
\text { generated in a month } \\
\text { from the reengineered } \\
\text { process. In } 2011 \text { Rs. } \\
14.5 \text { billion revenue } \\
\text { was generated and in } \\
2012-13 \text { fiscal year the } \\
\text { revenue generated in } \\
8 \text { months was Rs. } 10.5 \\
\text { billion. }\end{array}$ & $\begin{array}{l}\text { It has nothing to } \\
\text { do with revenue } \\
\text { however, the online } \\
\text { database with } \\
\text { search option has } \\
\text { reasonably reduced } \\
\text { the traveling cost of } \\
\text { students and others } \\
\text { concerned }\end{array}$ & No effect on revenue \\
\hline 504 & $\begin{array}{l}\text { Cost reduc- } \\
\text { tion }\end{array}$ & $\begin{array}{l}\text { Cost has eventually } \\
\text { increased due to the } \\
\text { RFID card and print- } \\
\text { ing cost of Rs. } 130 \\
\text { each however, in com- } \\
\text { parison to the revenue } \\
\text { generated in } 2011 \text { e.g. } \\
\text { Rs. } 14.5 \text { billion, cost } \\
\text { of cards was Rs. } 3.6 \\
\text { billion. Thus cost is } \\
\text { not an issue. }\end{array}$ & $\begin{array}{l}\text { Yes cost has sig- } \\
\text { nificantly reduced } \\
\text { (figures were not } \\
\text { provided) }\end{array}$ & No effect \\
\hline 506 & $\begin{array}{l}\text { Elapsed time } \\
\text { cycle reduced }\end{array}$ & $\begin{array}{l}\text { In previous process } \\
\text { there was no time- } \\
\text { frame mentioned i.e. } \\
\text { it could take a month } \\
\text { or a day due to no } \\
\text { accountability and } \\
\text { check and balance } \\
\text { however, with the } \\
\text { reengineered process } \\
\text { all the information } \\
\text { is collected at one } \\
\text { window within } 20 \text { min } \\
\text { while the issuance of } \\
\text { card take } 5 \text { days. }\end{array}$ & $\begin{array}{l}\text { Yes to a reasonable } \\
\text { extent. Depending } \\
\text { upon the request of } \\
\text { student i.e. we are } \\
\text { offering urgent and } \\
\text { normal services. } \\
\text { Urgent services take } \\
\text { one day whereas } \\
\text { normal takes } 7 \text { days. } \\
\text { However, the fee } \\
\text { of urgent services } \\
\text { is double to the } \\
\text { normal. }\end{array}$ & $\begin{array}{l}\text { Yes very much. Now the } \\
\text { office of administration } \\
\text { doesn't need to visit each } \\
\text { department and collect } \\
\text { information. As the system } \\
\text { generates reports on daily, } \\
\text { weekly, and monthly basis } \\
\text { on single click. }\end{array}$ \\
\hline
\end{tabular}




\begin{tabular}{|l|l|l|l|l|}
\hline 507 & $\begin{array}{l}\text { Customer } \\
\text { satisfaction }\end{array}$ & $\begin{array}{l}\text { Customers are highly } \\
\text { satisfied with the } \\
\text { international standard } \\
\text { driving license and } \\
\text { the fast track services } \\
\text { provided under the } \\
\text { one roof. Problems } \\
\text { that were faced by } \\
\text { customer previously } \\
\text { are also solved. }\end{array}$ & $\begin{array}{l}\text { Customer satisfac- } \\
\text { tion and reduction } \\
\text { in their fatigue was } \\
\text { the major objective } \\
\text { behind the reengi- } \\
\text { neering and it has } \\
\text { been successfully } \\
\text { achieved. }\end{array}$ & $\begin{array}{l}\text { Yes as the recipients of } \\
\text { healthcare services and the } \\
\text { attendants are facilitated in } \\
\text { every service they seek in a } \\
\text { proper manner therefore, } \\
\text { they are satisfied }\end{array}$ \\
& & \\
\hline
\end{tabular}

While summarizing the overall effect of change on the overall performance of an organization, a set of questions were asked to collect evidences (results are shown in Table VI). Performance of CDLA has been remarkably improved with $80 \%$ success in achieving the expected results. Edu1 has also showed moderate improvement and achievements as compared to planned objectives whereas Hosp1 is struggling in achieving their results. The reason for not achieving expected results in the case of Hosp 1 might be because the change was incremental in nature and not radical.

Table VI: Organizational performance overview (after Reengineering)

\begin{tabular}{|l|l|l|l|l|}
\hline ID & Q\# & CDLA & Edu1 & Hosp1 \\
\hline 601 & $\begin{array}{l}\text { Average } \\
\text { increase in } \\
\text { revenue }\end{array}$ & Up to $50 \%$ & $5-6 \%$ & NIL \\
\hline 602 & Cost/income & $10 \%$ improvement & $12 \%$ & NIL \\
\hline 603 & $\begin{array}{l}\text { Average } \\
\text { elapsed time } \\
\text { cycle }\end{array}$ & $31-40 \%$ improvement & $20-30 \%$ & $40-50 \%$ \\
\hline 604 & $\begin{array}{l}\text { Customer } \\
\text { satisfaction }\end{array}$ & $\begin{array}{l}\text { Always meets expec- } \\
\text { tations }\end{array}$ & $\begin{array}{l}\text { Consistently meets } \\
\text { expectation }\end{array}$ & To some degree \\
\hline 605 & BPR Success & $80 \%$ successful & $60-70 \%$ & $30-40 \%$ \\
\hline
\end{tabular}

At the end of interviews top management was asked about CSF and CFF and it was found that CDLA considered many CSFs and CFFs while planning and implement change whereas Hosp1 ignored the importance of so many elements and took them lightly. Top management commitment and support, use of IT, teamwork and cooperative environment, education and training, involvement of HR in implementation, and scope of change were among the major CSFs of CDLA (see table VII). Top Management commitment, use of IT, collaboration, scope of change, proper planning and strategy, customer focus were CSFs according to Edu 1 while only use of IT and operational changes were considered to be CSFs of BPR by the team of Hosp1. 
BPR however, it was an ignorant part of Hosp1 which resulted in failure of project.

Table VII: CSF and CFF

\begin{tabular}{|l|l|l|l|l|}
\hline ID & Q\# & CDLA & Edu1 & Hosp1 \\
\hline 701 & $\begin{array}{l}\text { What are the } \\
\text { critical suc- } \\
\text { cess factors of } \\
\text { BPR in this } \\
\text { organization? }\end{array}$ & $\begin{array}{l}\text { Top management com- } \\
\text { mitment and support, } \\
\text { Use of IT, teamwork } \\
\text { and cooperative } \\
\text { environment, edu- } \\
\text { cation and training, } \\
\text { involvement of HR in } \\
\text { implementation, and } \\
\text { scope of change }\end{array}$ & $\begin{array}{l}\text { Top Management } \\
\text { scope of change, } \\
\text { proper planning } \\
\text { and strategy, cus- } \\
\text { tomer focus. }\end{array}$ & $\begin{array}{l}\text { Use of IT, operational } \\
\text { changes }\end{array}$ \\
\hline 702 & $\begin{array}{l}\text { What are the } \\
\text { critical failure } \\
\text { factors? }\end{array}$ & $\begin{array}{l}\text { Fear of failure, and } \\
\text { change itself }\end{array}$ & $\begin{array}{l}\text { Lacking in basic } \\
\text { concepts of BPR, } \\
\text { team building } \\
\text { efforts. }\end{array}$ & $\begin{array}{l}\text { Lack of confidence in staff, } \\
\text { vague methodology, inter } \\
\text { departmental conflicts, } \\
\text { Technological knowhow }\end{array}$ \\
\hline
\end{tabular}

Analysis and comparisons of three cases shows that the nature of BPR is dynamic i.e. it varies from case to case and depends on the need of an organization however, the reasons for reengineering remains the same in most cases. The antecedents of BPR are similar to developed world efforts as well i.e. radical change, fast and effective services, improving service quality, reduce cost. Moreover, the additional reasons revealed from reengineering efforts in public sector were to monitor and control the customer services, to bring transparency, to reduce corruption and centralization of process.

\section{Discussion}

This study was conducted to study the BPR initiatives taken in public sector of Pakistan. The objectives of the study were to identify the reasons for BPR, to investigate the outcome of BPR, to study the effect of BPR on overall organization, lessons learned, and to study the relationship of BPR and ERP.

Before getting into detail discussion about the BPR initiatives in public sector of developing economies it is important to verify whether these changes were actually reengineering or not? Therefore, cases were compared with the characteristics and essentials of BPR presented by Hammer and Champy (1993), Biazzo (1998), McKay and Radnor (1998). It was found that the processes in all three cases were restructured and reengineered. Aim of the organization was also according to the definition of the phenomenon of BPR (as defined byHammer and Champy (2001), Davenport (1993), Talwar (1993). Another key element of Hammer's definition of BPR was "Performance" which was found to be the major reason of reengineering in these 
organizations (i.e. improving performance in terms of quality, service, and speed).

CDLA and Edu1cases showed that the processes were radically redesigned and restructured whereas in Hosp1 the process was somewhat incremental in nature. Up on the comparison of BPR initiatives in these cases, CDLA showed a complete slate which was similar to BPR efforts of private sector (MacIntosh, 2003b, Halachmi and Bovaird, 1997) while the remaining cases are typical example of BPR in public sector (McAdam and Donaghy, 1999, Gulledge Jr and Sommer, 2002, Thong et al., 2000). As far as modeling is concerned, CDLA used IDEFO (as suggested by Bevilacqua et al. (2013), Kundu et al. (2012), Feldmann and Tieso (1998) etc. and used by many consultants as well as firms across the globe. Edu1 and Hosp 1 has used process mapping and flowcharts for reengineering (as suggested byKettinger et al. (1997), Soliman (1998), Hunt (1996), Aghdasi et al. (2010) etc.). Almost every BPR framework (see for example Motwani et al. (1998), Lin et al. (2002), Al-Mashari and Zairi (2000), Manganelli and Klein (1994), Harrison and Pratt (1993)) suggests that first the top management should understand their need and problem identification. Afterwards a clear vision is required to provide clear direction. In the cases under study, it was found that the first step was followed however, there was no clear vision. Furthermore, there was no evidences of following a proper theory, framework, and methodology for BPR in public sector cases from Pakistan however, there were similarities with the methodology presented by Manganelli and Klein (1994) for process reengineering (i.e. preparation, identification, vision, technical and social, and transformation).

Tikkanen and Pölönen (1996) argued that public sector of Finland had limited BPR projects (i.e. limited in scope and focus) whereas in Pakistan the cases vary in scope and focus. CDLA and Edu1 have undertaken comprehensive BPR initiative while on the other hand Hosp1 had a limited BPR initiative. Chan and Peel (1998) surveyed 37 organizations from different sectors and found that a common attribute of reengineering was to improve results and customer service. These objective or reengineering were common among the cases from Pakistan as well.

\subsection{Reasons of BPR}

According to Thong et al. (2000) government of both developed and under developing countries are utilizing BPR as a vital tool for bringing reforms in their respective public sectors. These reforms are aimed to provide efficient services, to improve transparency, effective services delivery, and to meet the demands of customers. Grover et al. (1999) believes that BPR projects are initiated to reduce cost, reduction time consumed, involve IT and client-server architecture, and to utilize organizational resources effectively. Guimaraes (1997) stated that BPR is initiated to meet changes in customer's demands, to compete with the changes in market, and 
to utilize the innovative technologies. Pollitt and Bouckaert (2000) argued that the reasons for BPR initiatives by any organization are to remove non-value-added activities from the process so that operating cost is reduced, to reduce elapsed time, and to improve quality of products and services. Hammer and Champy (1993) considers that the reasons for BPR initiatives are customer, competition, and change. BPR can be fruitful when process is aligned with the customer's requirement in long-term. It may not be effective in short-term due to the change enduring. Furthermore, when the company thinks they are captured and occupied, at that stage the company needs to rethink and come up with some solution (change). Similar reasons were found in this study in the public sector of Pakistan i.e. to meet changing demands of customer, market driven, to improve services, to bring efficiency, utilization of IT and automation, and to bring transparency and accountability.

Venkartraman (1991a) stated that the birth of BPR was mainly to align IT with organizational strategy. IT and automation replaced the paperwork in an organization and it enhances efficiency and supports vertical and horizontal communication processes. Similarly Smith (2003) argued that BPR is a tool to advance the communication within organization. CDLA and Edu1 initiated BPR to improve efficiency and also to automate their processes with the help of IT and innovative technologies. On the other hand, Hosp1 commenced BPR to improve communication and for record keeping. There are differences among the cases under study however; these differences are understandable and supported by Martinsons (2004) in his study on sample from China and stated that within same country different organizations can behave differently because of their policies and internal factors of organization as well as external pressures.

\subsection{Approach to BPR in developing country}

Theory suggests that there are many ways to approach BPR. Various studies suggested different models to approach BPR e.g. Muthu et al. (1999) suggested five steps model (prepare for BPR, Map and Analyze As-Is process, Design To-Be process, Implement, and Improve continuously), Furey (1993) suggested seven stages (Set Direction, Baseline and Benchmark, Create the Vision, Launch Problem Solving Projects, Design Improvements, Implement Change, and Embed Continuous Improvement), Harrison and Pratt (1993) suggested a five steps for BPR project (Determine Customer Requirements \& Goals for the Process, Map and Measure the Existing Process, Analyze and Modify Existing Process, Design a Reengineered Process, and Implement the Reengineered Process), Mayer et al. (1995) suggested six stages (Motivating Reengineering, Justifying Reengineering, Planning Reengineering, Setting up for Reengineering, As Is Description \& Analysis, and To-Be Design and Validation), 
and similarly Motwani et al. (1998) suggested six phases of BPR (understanding, initiating, programming, transforming, implementing, and evaluating) etc.. While comparing the cases from Pakistan it has been exhibited that they are not following any BPR model in particular however, the steps of planning, implementation and evaluation are followed. CDLA took almost one year at planning phase, pilot test at one district for six months and then implanting the new process in all districts of province. Likewise, Edu1 took six months in planning phase and then launching new process manually and after evaluating they initiated ERP and ICT into the new process. Nonetheless, Hosp1 also took nine months in planning and one year in implementation however, this project was not fruitful.

Ellspermannn and Robinson (1994) discussed three stage criteria; first make it evident to the end user (customer), secondly it should create wealth and provide competitive advantage and finally make BPR team comprising of top management and external professionals. First step was followed in all three cases however, second stage is more likely to be associated with private sector therefore; it was not followed in public sector of Pakistan. While comparing third stage with the finding of this study, it was found that CDLA and Edu1 made BPR teams comprising of top management and cross-functional teams however; they did not involve any external professionals and only Hosp1 utilized services of external professional but it was not fruitful (as they were unable to achieve their objectives).

Davenport (1993), Hammer and Champy (1993) believes BPR is a radical change. While reviewing the cases it was found that CDLA and Edu1 are examples of radical however, Hosp 1 was having an incremental change. Moreover, the authors suggested that it should be top-down participation and it is true in all three cases. IT remained a key enabler in all three cases as suggested in theory. Thus, study confirms that theory is not operational to its full extent in this part of world.

\subsection{Results of BPR initiative}

As a result of successful BPR project, organizations will have improved performance i.e. profit optimization and productivity (McKay and Radnor, 1998), improved performance, efficient and effectiveness, cost minimization and increase in production (Hammer and Champy, 1993), improved process delivery system, improved customer service level (Gunasekaran and Kobu, 2002b), competitive advantage (Magutu et al., 2001). These outcomes are equally found in pubic as well as private sector in developing and developed economies however, in public sector (particularly in the developing economies) there are additional results of BPR as well i.e. improved accountability, equity, fairness, transparency, and good governance (Debela, 2010). 
Malaysian government was able to improve personnel and financial management, efficient customer service, improvement in productivity and quality of service, and communication in intra as well as inter-organizations (Siddiquee, 2006, Siddiquee, 2007, Ahmad et al., 2003). Singapore was able to improve transparency and accountability, successfully launched one window operations to minimize unwanted interaction of staff and customers and also to reduce elapsed time, IT and automation of all departments to bring efficiency and effectiveness and also to reduce corruption, and to improve customer satisfaction (Sarker, 2006, Samaratunge et al., 2008). Bangladesh has also imitated BPR projects in their public sector which resulted in bringing transparency, reduction in corruption, control over the processes, accountability, professionalism and efficiency (Sarker, 2005). Nonetheless, these results are not fruitful all the times as according to Al-Mashari and Zairi (1999) 70\% of BPR efforts fail to produce desirable results. In Pakistan, BPR resulted in improving firm performance, customer satisfaction, reduction in operating cost, reduction in average elapsed time cycle, control over processes, transparency, accountability, reduction in unwanted interaction, improvement in communication channels, and also in replacement of old paperwork with state of the art technology. However, Hosp1 was unable to achieve its desirable objectives which clearly indicate that BPR is not always successful.

\subsection{Changes/Alterations in organization due to BPR}

Brynjolfsson et al. (2012) argued that change in one part of an organization will bring change in the rest of organization as well thus, in the three cases it was found that change in business process led to change in HR in CDLA, training program's objectives, strategic changes, and changes in organizational structure. However, this change in business process did not bring change in personnel of Eduland a slight change was reported in the organizational structure. On the other hand in case of Hosp1, the only concern of management was to change the business process while there were no evidences of change in people, change in structure, and change in strategy. Weerakkody et al. (2011) reported evidences from UK and Dutch's public sector and found that there were changes in an organization due to reengineering. On the other hand firms from Brazil and UK also showed differences in the way BPR affected the overall organizations (Belmiro et al., 2000a). Hence looking at the effects of process reengineering on the other organizational factors, it has been found that these changes varies from organization to organization and from the way BPR has been planned and on the type of organization (Zuo and Liu, 2010).

To insure success of BPR Ethiopian public sector downsized their HR (see for example Debela (2010)) and similar was reported from Bangladesh (Sarker, 2005) however, in case of Pakistan there was increase in HR in CDLA and Hosp1 but 
no changes in Edu1. Habib and Wazir (2012) stated that education and training of employees regarding change in an organization is vital for the success of BPR and hence proved in all three cases that training regarding new technology and process was given to the staff.

Customer, competition, and change itself is the key focus of BPR and organization should set their strategy to meet the requirement of customers, compete and gain competitive advantage and should always be ready to adapt and accommodate changes due to internal and external forces. (Hammer and Champy, 1993). CDLA and Edu1 has changed their organizational focus accordingly and is now customer centered however, Hosp1 has not changed their organizational strategies.

\subsection{ERP and BPR}

Gunasekaran and Kobu (2002a) argued that IT and ERP improves customer service level and the delivery system. Moreover,He (2004a) in his study stated that ERPaimsatintegratingfunctional-areainformationsystems within a company into a coherent, enterprise-wide, and web-enabled network, its implementation is especially challenging to enterprises in China because of high implementation costs, technical complexity, lack of information technology infrastructure, lack of well-trained employees, lack of incentives to state-owned enterprises, and a corporate culture different from that in the West. Furthermore, Huang and Palvia (2001) are also of the opinion that there is growing need to implement a total business solution which supports major functionalities of a business. ERP is intended to encounter these needs, and has been extensively accepted by organizations in developed countries. The major barrier in the implementation of ERP in developing countries is of its external environment i.e. economic condition, cultural issues, and basic infrastructure issues. Chan and Land (1999) believes that IT and innovative technologies are key enablers of BPR and especially in this fast changing technological era. Huq and Martin (2006) ERP and BPR are highly correlated and they support each other in achieving organizational goals and objectives. Successful cases are reported in literature showing ERP-led BPR implementations (see for example (Huq et al., 2006)). However, on the other hand, NG et al. (1999) concluded that ERP driven BPR projects are not successful just because of the limitedness of ERP. This shows the importance of ERP and IT in business processes and there are several examples of studies conducted on the need to change processes for accommodating ERP and other automation initiatives from public as well as private sectors (NG et al., 1999, Huq and Martin, 2006, Koch, 2001, Parr and Shanks, 2000, Scheer and Habermann, 2000). Cases under study showed that ERP and IT was key enabler and reason for BPR which is in accordance with the literature. 


\subsection{Critical Success and Failure Factors}

Several studies have identified number of CSF and CFF (shared values, information technology support, team work, performance outcome, communication, education and training, customer focus, human factor, scope of changes, organizational structure) that are essential for the success and failure of the BPR project. (see for example (Al-Mashari and Zairi, 1999, Herzog et al., 2007, Magutu et al., 2010, Davenport, 1995, Habib, 2013, Habib and Wazir, 2012)). Top management and employee's commitment, effective communication, teamwork and their empowerment are the important CSFs in public sector (McAdam and Donaghy, 1999). This study showed different approaches towards the CSF and CFF of BPR project. Comparing to the available literature, the top management of CDLA and Edu1 had a clear idea of key components that may lead to success or failure and therefore, these organizations had considered all of the stated above components while planning and implementing BPR however; on the other hand, Hosp1 did not consider these factors therefore it had negative impact on the success of project.

\subsection{Lessons Learned}

After analyzing the results of cases from public sector of developing country, following lessons are learned;

1. Theory and frameworks of BPR are not followed as suggested by literature and studies from developed world.

2. Another important lesson learnt here from this study is that in developed world these efforts are more linked with the company's vision and strategies while in developing country they are not.

3. The more concern of developing world is on automation because in developing world especially the public sector is not digitalized yet and most of public sector organizations are using old paperwork.

4. Public sector of Pakistan is facing numerous challenges i.e. corruption, transparency and accountability, lack trust of citizens on the system, efficiency and performance. To overcome these issue, top management and bureaucracy believes that automation, IT and ERP will help in overcoming above stated problems.

5. In this part of world, the top management is not that clear about the change itself as compared to developed world. Theory suggests that they should be clear about the reasons for change i.e. why to change current system, what are the objectives behind the change and how to bring radical change clear vision and committed team is very important to reduce chances of failure whereas the employee's motivation and understanding the purposes of change also plays important role in reengineering. 
6. Public sector's employees in Pakistan are reluctant to new technology (mostly those employees that are of 40 and above age) therefore; to break a status quo of employees, government needs to design intensive training programs so that the reengineering is implemented smoothly. Developed world is spending billions on the development and training of employees whereas developing world (particularly public sector) is not recognizing the importance of training programs (Habib and Wazir, 2012).

7. Public sector of Pakistan is having bureaucratic structure thus the planning and implementation is done at different places. Furthermore, the chain (hierarchy) is very tall thus resulting in wastage of time. This indicates that the developing counties are not adapting to the private sector's management tools properly.

8. Literature states that although IT is an integral part of BPR and it takes advantage of the latest technology thus; in this part of world, BPR efforts are found to be used as a tool to adjust ERP and automation in public sector's organizations. It can be said that ERP resulted in BPR or vice versa.

9. BPR is a reactive approach in Pakistan's public sector and not a proactive approach. The reason for being reactive approach is that this country is still a developing country and therefore, it needs to overcome so many obstacles to improve current system radically.

\section{Conclusion}

This study was conducted to investigate public sector's BPR initiatives from a developing country (Pakistan). Three cases (that were already undergone through BPR implementation) were selected from public sector (working under provincial government) for comparative analysis with each other and with theory. CDLA and Edu1 reengineered their front office and customer's operation process to improve quality of service, reduce elapsed time cycle, and to improve customer satisfaction. On the other hand Hosp1 reengineered the communication channels. It has been found that for successful reengineering top management clarity of purpose is very important. Furthermore, involvement of cross-functional teams will help effectively in planning as well as in implementation. Development of HR with the help of communication and training plays vital role in successful implementation. Moreover, IT and ERP remained an integral part of BPR in this part of world which shows the important role of technology in organizational changes. Reason for failure of BPR efforts in healthcare sector was due to lack of clear vision, lack of commitment, and incremental change rather than radical. It was also observed that external consultants cannot help organization unless top management is clear and understand the problems. It is concluded from this study that BPR is equally applicable and successful in public sector as compared to private sector. Furthermore, it is also important to 
note that BPR is contributing significantly in service sector of developing countries however; theory is not followed in its true spirit. Similarly, evidences are showing that BPR frameworks (models) are not followed as well. Although there are much to learn and consider during planning and implementing phases of reengineering initiative however; it is a good sign and shows the seriousness of public sector that they are adopting latest management tools for performance improvement and also are considering the importance of citizens. Reengineering in public sector of Pakistan shows the intention of government to provide efficient services to the citizens and it is also showed that the government wants to improve the process by using latest technology. BPR is alive and is working well in this part of world however the process is very slow paced hence; the results are delivered slowly as well.

\section{References}

AGHDASI, M., ALBADVI, A. \& OSTADI, B. 2010. Desired organisational capabilities (DOCs): mapping in BPR context. International Journal of Production Research, 48, 2029-2053.

AHMAD, S. A., MANSOOR, N. \& AHMAD, K. A. 2003. The Malaysian bureaucracy: Four decades of development, Malaysia, Pearson Malaysia.

AL-MASHARI, M., IRANI, Z. \& ZAIRI, M. 2001. Business process reengineering: a survey of international experience. Business Process Management Journal, 7, 437-455.

AL-MASHARI, M. \& ZAIRI, M. 1999. BPR implementation process: an analysis of key success and failure factors. Business Process Management Journal, 5, 87-112.

AL-MASHARI, M. \& ZAIRI, M. 2000. Revisiting BPR: a holistic review of practice and development. Business Process Management Journal, 6, 10-42.

ALBIZU, E. \& OLAZARAN, M. 2006. PR implementation in Europe: the adaptation of a management concept. Blackwell Publishing Ltd, 21, 43-58.

ASIAN REPORT 2010. Reforming Pakistan's Civil Service. Islamabad/Brussels: International Crisis Group.

BABBIE, E. R. 2012. The practice of social research, Wadsworth Publishing Company.

BELMIRO, GARDINER, SIMMONS \& RENTES 2000a. Are BPR practitioners really addressing business processes? International Jouranal of Operation and Production Management, 20, 1183-1203.

BELMIRO, T., GARDINER, P., SIMMONS, J. \& RENTES, A. 2000b. Are BPR practitioners really addressing business processes? International journal of Operations and production management, 20, 1183-1202.

BELMIRO, T. R., GARDINER, P. D., JOHN E.L. SIMMONS \& ANTONIO F. RENTES 2000c. Are BPR Practitioners really addressing busniess processes? International Jouranal of Operation and Pro- 
duction Management, 20, 1083-1202.

BERNARD, H. R. 2012. Social research methods: Qualitative and quantitative approaches, SAGE Publications, Incorporated.

BEVILACQUA, M., CIARAPICA, F. E. \& GIACCHETTA, G. 2013. BPR methods applied to a manufacturer in the domotics sector. Business Process Management, 444, 389-405.

BIAZZO, S. 1998. A critical examination of the business process re-engineering phenomenon. International Journal of Operations \& Production Management, 18, 1000-1016.

BROWNE, J. \& O'SULLIVAN, D. 1995. Reengineering the Enterprise, Galway, Ireland, , Cahpman \& Hall, .

BRYNJOLFSSON, E., RENSHAW, A. \& VAN ALSTYNE, M. 2012. The matrix of change. Sloan Management Review, 28.

CHAMPY, J. 1994. The state of Reengineering. Computer Science Corporation.

CHAN \& LAND, C. 1999. Implementing reengineering using information technology. Business Process Management Journal, 5, 311-324.

CHAN, S. \& PEEL, D. 1998. Causes \& Impact of reengineering. Business Process Management Journal, 4, 44-55.

CHOI, C. J. 1995. Samsung: Re-engineering Korean style. Long Range Planning, 28, 74-80.

COLIN, J. \& COULSON, T. 1997. The future of he organization's achieving excellence through business transactions. Management Services, 41, 16-18.

COULSON-THOMAS, C. J. 1995. Business process re-engineering: the development requirements and implications. Executive Development, 8, 3-6.

CRESWELL, J. W. 2002. Research design: Qualitative, quantitative, and mixed methods approaches. Thousand Oaks: CA: Sage.

DAVENPORT 1993. Process Innovation: Reengineering Work through Information Technology, , Boston: MA, Harvard Business School Press.

DAVENPORT, T. 1995. Business process reengineering: where it's been, where it's going. In: GROVER, V. \& KETTINGER, W. J. (eds.) Business Process Change. Reengineering Concepts, Methods and Technologies, . Harrisburg: Idea Group Publishing, .

DEBELA, T. 2010. Business process reengineering in Ethiopian public organizations: the relationship between theory and practice. Journal of Business and Administrative Studies, 1, 20-59.

EISNER, H. 2000. Reengineering yourself and your company: from engineer to manager to leader. Artech House Technology Management and Professional Development Library. 
ELLSPERMANNN, S. \& ROBINSON, S. A. 1994. Mainstreaming innovation into business process improvement Engineering Management Journal, 6.

ERIM, A. \& VAYVAY, Ö. 2010. Is the business process reengineering (bpr) proved itself to be a trustable change management approach for multinational corporations? Case studies from the literature Journal Of Aeronautics And Space Technologies, 4, 23-30.

FELDMANN, C. G. \& TIESO, J. V. 1998. The Practical guide to business process reengineering using IDEFO, New York: NY, Dorset House Pubulishing Co. Inc.

FUREY, R. T. 1993. A Six Step Guide to Process Reengineering. Planning Review, 21, $20-23$.

GALLUP PAKISTAN 2012. Cyber Letter. Islamabad: Gallup Pakistan.

GOKSOY, A., OZSOY, B. \& VAYVAY, O. 2012. Business Process Reengineering: Strategic Tool for Managing Organizational Change an Application in a Multinational Company. International Journal of Business and Management, 07, 89-112.

GRINT, K. \& WILLCOCKS, L. 1995. Business process re-engineering in theory and practice: business paradise regained? New Technology, Work and Employment, 10, 99-109.

GROVER, V., FIEDLER, K. D. \& TENG, J. T. 1999. The Role of Organizational and Information Technology Antecedents in Reengineering Initiation Behavior. Decision Sciences, 30, 749-781.

GUBA, E. G. \& LINCOLN, Y. S. 1994. Competing paradigms in qualitative research. Handbook of qualitative research, 2, 163-194.

GUIMARAES, T. 1997. Empirically testing the antecedents of BPR success. International Journal of Production Economics, 50, 199-210.

GULLEDGE JR, T. R. \& SOMMER, R. A. 2002. Business process management: public sector implications. Business Process Management Journal, 8, 364-376.

GUNASEKARAN, A. \& KOBU, B. 2002a. Modeling and Analysis of Business Process Reengineering. . International Jouranal of Operation and Production Management, 40, 2521-46.

GUNASEKARAN, A. \& KOBU, B. 2002b. Modelling and analysis of business process reengineering. International Journal of Production Research, 40, 28.

HABIB, N. M. 2011. Role of training and teamwork in the successful implementation of BPR, Business Process Reengineering: A case of public sector of Khyber Pakhtunkhwa (KPK), VDM Verlag Dr. Müller HABIB, N. M. 2013. Understanding Critical Success and Failure Factors of Business Process Reengineering. International Review of Management and Business Research, 2, 1-10.

HABIB, N. M. \& WAZIR, I. M. 2012. Role of Education and Training in the Successful Implementation of Business Process Reengineering: A case of Public Sector of Khyber PakhtunKhwa (KPK). World Journal of Social Sciences, 2, 172-185. 
HALACHMI, A. \& BOVAIRD, T. 1997. Process reengineering in the public sector: Learning some private sector lessons. Technovation, 17, 227-235.

HAMMER, M. 1990. Reengineering Work: Don't automate, elaborate. HBR, July-August, . 104-112.

HAMMER, M. \& CHAMPY, J. 1993. Reengineering the corporation, London Nicholas Brealy.

HAMMER, M. \& CHAMPY, J. 2001. Reengineering the Corporation - A Manifesto for Business Revolution. New York, USA: Harper Business.

HAMMER, M. \& STANTON, S. A. 1995. The Reengineering Revolution: A Handbook, HarperBusiness.

HARRISON, D. B. \& PRATT, D. M. 1993. A methodology for Reengineering Business. Planning Review, 21, 6-11.

HE, X. 2004a. The ERP challenge in China: a resource-based perspective. Information Systems Journal, $14,153-167$.

HE, X. J. 2004b. The ERP challenge in China: A Resource based Perspective. Information system Journal, 14, 153-167.

HERZOG, N. V., POLAJNAR, A. \& TONCHIA, S. 2007. Development and validation of business process reengineering (BPR) variables: a survey research in Slovenian companies. International Journal of Production Research, 45, 5811-5834.

HUANG, Z. \& PALVIA, P. 2001. ERP implementation issues in advanced and developing countries. Business Process Management Journal, 7, 276-284.

HUNT, V. D. 1996. Process mapping: how to reengineer your business processes, John Wiley \& Sons.

HUQ, Z., HUQ, F. \& CUTRIGHT, K. 2006. BPR through ERP: Avoiding change management pitfalls. Journal of Change Management, 6, 67-85.

HUQ, Z. \& MARTIN, T. N. 2006. The recovery of BPR implementation through an ERP approach: A hospital case study. Business Process Management Journal, 12, 576-587.

JURISCH, C. M., IKAS, C., PALKA, W., WOLF, P. \& KRCMAR, H. 2012. A Review of Success Factors and Challenges of Public Sector BPR Implementations. 45th Hawaii International Conference on System Sciences.

KETTINGER, W. J., TENG, J. T. C. \& GUHA, S. 1997. Business process change: a study of methodologies, techniques and tools: MIS Quarterly, March. MIS Quarterly, 21.

KIANI, K. 2013. IMF insists on reforms and policy changes. Dawn, 19th January, 2013.

KNIGHTS, D. \& WILLMOTT, H. 2000. The reengineering revolution?: critical studies of corporate change, London, UK, SAGE Publications Ltd.

KOCH, C. 2001. BPR and ERP: realising a vision of process with IT. Business Process Management 
Journal, 7, 258-265.

KUNDU, P., RATHA, B. \& DAS, D. 2012. Revisiting BPR: A New Framework \& Model for Future. International Journal of Engineering Research and Technology, 1.

LIN, F., YANG, M. \& PAI, Y. 2002. A generic structure for business process modeling. Business Process Management Journal, 8, 19-41.

MACINTOSH, R. 2003a. BPR: alive and well in the public sector. International Journal of Operations \& Production Management, 23, 327-344.

MACINTOSH, R. 2003b. BPR: alive and well in the public sector. International Jouranal of Operation and Production Management, 23, 327-344.

MACKENZIE, N. \& KNIPE, S. 2006. Research dilemmas: Paradigms, methods and methodology. Issues in educational research, 16, 193-205.

MAGLITTA, J. 1995. IS seen as reengineering blockade. Computerworld, 29.

MAGUTU, P. O., NYAMWANGE, S. O. \& KAPTOGE, G. K. 2001. Business Process Reengineering For Competitive Advantage. African Journal of Business \& Management (AJBUMA), 1, 135-150.

MAGUTU, P. O., NYAMWANGE, S. O. \& KAPTOGE, G. K. 2010. Business Process Reengineering For Competitive Advantage; Key Factors That May Lead To the Success or Failure of the BPR Implementation (The Wrigley Company). African Journal of Business \& Management (AJBUMA), 1, 135-150.

MANGANELLI, L. R. \& KLEIN, M. M. 1994. The Reengineering Handbook: A Step-by-Step Guide to Business Transformation, NY, American Management Association, New York.

MARTINSONS, M. G. 2004. ERP in China: One package, Two Profiles. Communication of the ACM. July ed.: ACM New York, NY, USA

MAYER, R. J., BENJAMIN, P. C., CARAWAY, B. W. \& PAINTER, M. 1995. A framework and a suite of methods for business process reengineering. In: GROVER, V. \& KETTINGER, W. J. (eds.) Business Process Change: Reengineering Concepts, Methods and Technologies. . London: : Idea Group Publishing, . MCADAM, R. \& DONAGHY, J. 1999. Business process re-engineering in the public sector: A study of staff perceptions and critical success factors Business Process Management Journal, 5, 33-52.

MCKAY, A. \& RADNOR, Z. 1998. A characterization of a business process. International Journal of Operations \& Production Management, 18, 13.

MILES, M. B. \& HUBERMAN, A. M. 1994. Qualitative data analysis: An expanded sourcebook, Thousand Oaks, CA, Sage.

MOTWANI, J., KUMAR, A., JIANG, J. \& YOUSSEF, M. 1998. Business process reengineering: A theoretical framework and an integrated model. International Journal of Operations \& Production Management, 18, 964-977. 
MUTHU, S., WHITMAN, L. \& CHERAGHI, H. S. 1999. BUSINESS PROCESS REENGINEERING: A CONSOLIDATED METHODOLOGY. International Conference on Industrial Engineering Theory, Applications and Practice, San Antonio, Texas, USA, 05.

NG, J. K. C., IP, W. H. \& LEE, T. C. 1999. A paradigm for ERP and BPR integration. International Journal of Production Research, 37, 2093-2108.

PARR, A. N. \& SHANKS, G. A taxonomy of ERP implementation approaches. 33rd Annual Hawaii International Conference, January 20002000 Hawaii. IEEE, 10.

POLLITT, C. \& BOUCKAERT, G. 2000. Public Management Reform: A Comparative Analysis OUP Oxford.

RANGANATHAN, C. \& DHALIWAL, J. S. 2001. A survey of business process reengineering practices in Singapore. Information and Management Journal, 39, 125-134.

REEVES-ELLINGTON, R. 1995. Organizing for Organizational Effectiveness: Ethnicity and Organizations. Human Organization, 53, 249-263.

SAMARATUNGE, R., ALAM, Q. \& TEICHER, J. 2008. The new public management reforms in Asia: a comparison of south and southeast Asian countries. International Review of Administrative Sciences, 74, 25-46.

SARKER, A. 2005. New public management, service provision and non-governmental organizations in Bangladesh. Public Organization Review, 5, 249-271.

SARKER, A. 2006. New public management in developing countries: an analysis of success and failure with particular reference to Singapore and Bangladesh. International Journal of Public Sector Management, 19, 180-203.

SCHEER, A. W. \& HABERMANN, F. 2000. Enterprise resource planning: making ERP a success. Communications of the ACM, 43, 57-61.

SENTANIN, F. O., SANTOS, C. A. F. \& JABBOUR, J. C. 2008. Business process management in a Brazilian public research centre. Business Process Management Journal, 14, 483-496.

SIDDIQUEE, N. A. 2006. Public management reform in Malaysia: Recent initiatives and experiences. International Journal of Public Sector Management, 19, 339-358.

SIDDIQUEE, N. A. 2007. Public service innovations, policy transfer and governance in the Asia-Pacific region: The Malaysian experience. Journal of Administration and Governance, 2, 81-91.

SIDDIQUI, H. 2013. New Rules for State-Owned Enterprises in Pakistan. 21 March, 2013 ed. CIPE: CENTER FOR INTERNATIONAL PRIVATE ENTERPRISE.

SMITH, M. 2003. Business Process Redesign: Correlates of success and failure. The Quality Management Journal, 2, 38-49. 
SMITH, M. E. 2002. Success rate of different types of organizational change. Performance Improvement, 41, 26-33.

SOLIMAN, F. 1998. Optimum level of process mapping and least cost business process re-engineering. International Jouranal of Operation and Production Management, 18, 810-816.

STAHL, D. A. 1998. Reengineering: The Key to Survival and Growth under PPS. Nursing Management, 29, 168.

SWANSON, A. R. \& HOLTON III, F. E. 2005. Research in Organizations: Foundations and Methods of Inquiry, San Francisco, California, Berrett-Koehler Publishers, Inc.

SYCHOWICZ, J. 2008. Successful predictions of Business Process Reengineering (BPR) in top companies in the European Union. Masters degree Economics, Wein Univeristy.

TALWAR, R. 1993. Business re-engineering-a strategy-driven approach. Long Range Planning, 26, 22-40.

THONG, J. Y., YAP, C. S. \& SEAH, K. L. 2000. Business process reengineering in the public sector: the case of the Housing Development Board in Singapore. Journal of Management Information Systems, 17, 245-270.

TIKKANEN, H. \& PÖLÖNEN, P. 1996. Business process re-engineering projects in Finland: An evaluation of change management in 21 large Finnish organizations. Business Process Re- engineering and Management Journal, 2, 10-25.

TRANSPARENCY INTERNATIONAL 2011. CORRUPTION PERCEPTIONS INDEX 2011. Berlin, Germany: Transparency International, International Secretariat.

VENKARTRAMAN, N. 1991a. The Corporation of the 1990s: Information Technology and Organizational Transformation. In: MORTON, M. S. S. (ed.). New York, NY: Oxford University Press.

VENKARTRAMAN, N. 1991b. The Corporation of the 1990s: Information Technology and Organizational Transformation. New York: Oxford University Press.

WEERAKKODY, V., JANSSEN, M. \& DWIVEDI, Y. K. 2011. Transformational change and business process reengineering (BPR): Lessons from the British and Dutch public sector. Government Information Quarterly, 28, 320-328.

ZAHEER, A. 2009. ANALYZING BUSINESS PROCESSES: PROPOSING AND TESTING A MODEL OF EMPLOYEE AND ORGANIZATIONAL PERFORMANCE. DOCTOR OF PHILOSOPHY IN MANAGEMENT SCIENCES PhD Foundation University, Islamabad.

ZAHEER, A., MUSHTAQ, K. \& ISHAQ, M. 2008. Reengineering the procurement process in a public sector organization: A case study. International Bulletin of Business Administration, 3, 30-43.

ZUO, L. \& LIU, Y. 2010. Organizational change pattern based on business process reengineering. International Conference on E-Business and E-Government (ICEE). IEEE. 